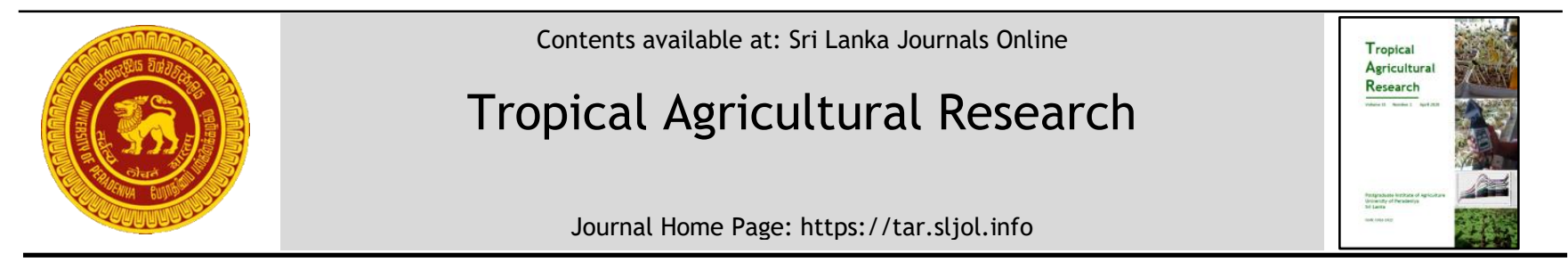

\title{
A Comparison of Chemical Profiles of Callus, Plant and Agarwood Extracts of Gyrinops walla using Thin Layer Chromatography
}

\author{
S. Selvaskanthan ${ }^{1 *}$, D.B.R. Kaushalya ${ }^{1}$, D.K.N.G. Pushpakumara ${ }^{1,2}$, L. Jayasinghe ${ }^{3}$ and J.P. Eeswara ${ }^{1,2}$ \\ ${ }_{1}^{1}$ Postgraduate Institute of Agriculture, University of Peradeniya, Peradeniya, Sri Lanka \\ ${ }^{2}$ Department of Crop Science, Faculty of Agriculture, University of Peradeniya, Peradeniya, Sri Lanka \\ ${ }^{3}$ National Institute of Fundamental Studies, Kandy, Sri Lanka
}

\section{ARTICLE INFO}

\section{Article history:}

Received: 19 September 2019

Accepted: 10 November 2019

Available online: 1 April 2020

\section{Keywords:}

Agarwood

Callus

Gyrinops walla

Plant growth regulators

Thin layer chromatography

\section{Citation:}

Selvaskanthan, S., Kaushalya, D.B.R., Pushpakumara, D.K.N.G., Jayasinghe, L. and Eeswara, J.P. (2020). A Comparison of Chemical Profiles of Callus, Plant and Agarwood Extracts of Gyrinops walla using Thin Layer Chromatography. Tropical Agricultural Research, 31(2): 97105.

DOI: http://doi.org/10.4038/tar.v31i2.8371

Selvaskanthan, S. iD https://orcid.org/ 000-0002-9646-6862

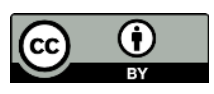

*Corresponding author : ssaru75@gmail.com

\begin{abstract}
Agarwood produced by Gyrinops walla_Gaertner, an endemic plant species of Sri Lanka, arguably the costliest wood, is used as a major constituent in cosmetic industries. Application of plant cell culture technique serves as the best alternative for the production of fragrance compounds of $G$. walla while ensuring the sustainability of the species. Using the advantages of plant cell culture and Thin Layer Chromatography (TLC), a preliminary study was carried out to compare the phytochemical constituents of callus and plant extracts (i.e stem, leaves, bark and agarwood) of $G$. walla. Different callus lines were developed on MS and modified MS media with reduced level of $\mathrm{NH}_{4} \mathrm{NO}_{3}$, supplemented with different combinations and concentrations of plant growth regulators and multiplied. Freeze dried samples were extracted with hexane, ethyl acetate and methanol and run on a TLC plate under different eluting solvent systems. A higher number of TLC spots were observed in the ethyl acetate extracts of all samples, under 15 percent methanol: chloroform solvent system. Based on TLC chemical profiles of all callus lines, MS media added with $1.0 \mathrm{mg} / \mathrm{L}$ BAP, 0.5 $\mathrm{mg} / \mathrm{L}$ kinetin and $0.1 \mathrm{mg} / \mathrm{L}$ 2,4-D and $1 / 2$ MS contained 1.0 $\mathrm{mg} / \mathrm{L} \mathrm{BAP}$ and $0.1 \mathrm{mg} / \mathrm{L} 2,4-\mathrm{D}$ were selected as best lines. The extracts of the selected two callus lines matched with the fingerprint profiles of best plant samples i.e stem, bark and agarwood. Compounds present in the extracts of callus samples, plant samples and agarwood, appearing at $\mathrm{Rf}=0.56,0.74$ and 0.78 , could be used as possible markers for $G$. walla. The chromatography profiling by TLC has proven the presence of similar phytochemical constituents in callus, plant samples and agarwood. Therefore, it can be concluded that plant cell culture technique guarantees the possibility to produce same compounds that are present in plant and agarwood of G. walla.
\end{abstract}




\section{INTRODUCTION}

Gyrinops walla is an endemic plant species to Sri Lanka, which belongs to family Thymalaeceae. The agarwood is the most valuable and exalted perfumery raw material obtained from the infected, resin-impregnated wood of $G$. walla (Subasinghe and Hettiarachchi, 2013). Increasing global demand for agarwood for agar oil as the base of world's most expensive perfumes, cause extensive exploitation of natural population of G. walla from tropical rain forest areas in Sri Lanka. Therefore, it is necessary to explore alternative and efficient techniques for fragrance compound production to meet the demand, while ensuring the sustainability of the species, since fragrance compound production of $G$. walla could become one of the major sources of foreign income to the country. Though artificial induction of agarwood compounds is a possible method, the formation of resinous portion inside the wood takes a considerably long time. Therefore, in vitro plant cell culture is a suitable and feasible method, which could be commercially exploited for the production of quality fragrance compounds (Shu et al., 2005; Okudera and Ito, 2009).

Callus develops in response to chemical or physical lesions under determinate hormonal conditions (Jeyaraman et al., 2013). The exogenous supply of plant growth regulators is necessary in calogenesis (Nurazah et al., 2009). This necessity refers to the type and concentration of plant growth regulators mainly auxins and cytokinins, genotype of the donor plant, and the endogenous content of hormones (Lima et al., 2008). Indeed, plant cell culture technique is found to have potentials in supplementing traditional agriculture in the industrial production of desirable plant metabolites in flavour and fragrance industries (Vanisree et al., 2004).

Though there are many sophisticated techniques to analyse the chemical constituents, thin layer chromatography (TLC) is the simplest and the most versatile technique, which has potential to detect even microgram quantities of particular chemicals within a short period. These advantages bring about the possibility of using this technique in screening the chemicals present in plant extracts (Itankar et al., 2015). The TLC fingerprint with a visible pattern of bands provides fundamental data of compounds present in a sample and can be defined as a set of characteristic chromatographic signals, whose comparison leads to unambiguous sample recognition. TLC also facilitates to analyse mixtures by separating the compounds and identifying them. Furthermore, TLC profiles can be used to construct the fingerprints for specific plant species for its identification.

Scientific studies on agarwood of $G$. walla have been mostly focused on chemical profiling of the wood and oils. Intensive work therefore needs to be undertaken to compare the chemical profiles of callus with plant and agarwood samples of $G$. walla. Hence, the present study was conducted for the identification of feasibility in producing chemical profiles similar to plant and agarwood of $G$. walla through cell culture technique in order to ensure the sustainable utilization of this plant.

\section{MATERIALS AND METHODS}

\section{Development of callus culture on different culture media}

Immature leaf explants were used to establish callus cultures and surface sterilization was performed as in the method described previously by Selvaskanthan et al. (2017). All tissue culture techniques were conducted under aseptic conditions in a laminar flow cabinet (Labgard Class II, Type A/B3). Explants were cultured on modified Murashige and Skooge (MS) medium (Murashige and Skooge, 1962) that contained half level of ammonium nitrate $\left(\mathrm{NH}_{4} \mathrm{NO}_{3}\right)$ supplemented with 3 percent sucrose $(\mathrm{w} / \mathrm{v})$, different concentrations and combinations of cytokinins such as 6-Benzylaminopurine (BAP), kinetin and auxins such as 2,4Dichlorophenoxy acetic acid (2,4-D), 1Naphthalene acetic acid (NAA) and Indole-3butyric acid (IBA). Medium $\mathrm{pH}$ was adjusted to 5.8 with $1.0 \mathrm{~mol} / \mathrm{L} \mathrm{HCl}$ or $\mathrm{NaOH}$ prior to solidifying with $0.2 \%(\mathrm{w} / \mathrm{v}$ ) Phytagel (Sigma, UK) and autoclaved at $120{ }^{\circ} \mathrm{C}, 15$ psi for 20 minutes. Callus lines were further multiplied by sub-culturing at 6 week-intervals as 
decided from growth curves. Based on percentage callus induction and growth kinetics 10 callus lines grown on different media (Table 1) were selected for the detection of chemicals by TLC.

Table 1: Medium composition of callus lines selected for TLC

\begin{tabular}{lllll}
\hline \multicolumn{1}{c}{$\begin{array}{c}\text { Medium and } \\
\mathbf{N H}_{4} \mathbf{N O}_{3} \text { (mg/L) }\end{array}$} & BAP (mg/L) & $\mathbf{2 , 4} \mathbf{D}(\mathbf{m g} / \mathbf{L})$ & Kinetin (mg/L) & Medium \\
\hline $\mathrm{MS} \mathrm{Medium}$ & 1.0 & 0.1 & & $\mathrm{C} 1$ \\
$\mathrm{NH}_{4} \mathrm{NO}_{3} 1650$ & & 0.5 & & $\mathrm{C} 2$ \\
& & 1.0 & $\mathrm{C} 3$ \\
& 2.0 & 0.1 & $\mathrm{C} 4$ \\
\cline { 2 - 5 } & 1.0 & & 0.1 & $\mathrm{C} 5$ \\
& & & 0.5 & $\mathrm{C} 6$ \\
\hline $\mathrm{MS} \mathrm{Medium}$ & & 0.1 & \\
$\mathrm{NH}_{4} \mathrm{NO}_{3} 198$ & 1.0 & 0.1 & & $\mathrm{C} 8$ \\
$\mathrm{NH}_{4} \mathrm{NO}_{3} 412.5$ & 1.0 & 0.1 & & $\mathrm{C} 9$ \\
$\mathrm{NH}_{4} \mathrm{NO}_{3} 825$ & 1.0 & & & $\mathrm{C} 10$ \\
\end{tabular}

Each callus line was separately harvested at the end of $4^{\text {th }}$ sub-culture. The harvested calli were freeze dried (Lyotrap- Plus; SB400467) until the weight became constant. Leaves, barks and stems were excised from the $G$. walla plants and freeze dried before storing in a refrigerator at $-20^{\circ} \mathrm{C}$ until analysis.

\section{Preparation of extracts}

Freeze dried calli were crushed to make a fine powder by using a mortar and a pestle. Plant samples and agarwood were ground using a heavy-duty grinder (WARING, HGBTWTS3, Waring Commercial, Torrington, USA). They were then subjected to ultrasound assisted solvent extraction by adding $100 \mathrm{ml}$ of hexane and placing in an ultrasonic cleaner (ROCKER ultrasonic cleaner, model- soner 206H) for 30 minutes of extraction period before filtering through Whatman number 1 filter paper. The solvent was evaporated to dryness using rotary evaporator (Heidolph, Laborota 4000), keeping the temperature below $40{ }^{\circ} \mathrm{C}$, at the speed of $90 \mathrm{rpm}$ to obtain viscous semi-dried crude extracts. This process was repeated thrice. The residual material was sequentially extracted with ethyl acetate and methanol and evaporated to dryness by rotary evaporator. These crude extracts were subjected to TLC analysis.
Selection of the best extraction and eluting solvents for silica gel thin layer chromatography

To choose the best mobile phase for best elution, two callus lines with good callus induction percentage and specific growth rate were used. Extracts were spotted using capillary tubes on TLC silica plates pre-coated on aluminium foil (Merck, 105554, TLC Silica gel $60 \mathrm{~F}$ ) and the solvents were allowed to evaporate completely. The spotted plates were placed in a chromatographic solvent chamber which contained 5 different eluting solvent systems viz: i. $15 \%$, ii. $10 \%$, iii. $5 \%$ Methanol $(\mathrm{MeOH})$ in Chloroform $\left(\mathrm{CHCl}_{3}\right)$, iv. $100 \% \mathrm{CHCl}_{3}$ and v. 7:3:1 $\mathrm{CHCl}_{3}: \mathrm{MeOH}: \mathrm{H}_{2} \mathrm{O}$, to select the suitable mobile phase. The TLC plate was propped vertically in solvent chamber and stand allowing sufficient time for elution. When the solvent front has nearly reached the top of the stationary phase, the plate was removed from the chamber and the developed TLC plates were air-dried. UV monitoring at appropriate wavelength $(254 \mathrm{~nm})$ was performed for a comprehensive detection of various compounds present in the crude extract using a UV lamp (VILBER LOURMART CN-15-LC, 230 V- 50/60 Hze). 
Based on numbers and intensity of TLC spots, best solvent extract was chosen for further studies.

\section{Detection of the effect of different plant growth regulators on the product synthesis by TLC}

Ethyl acetate extracts of all 10 callus lines (Table 1) were evaluated to study the effects of different plant growth regulators and nitrogen level of media on product synthesis by TLC. In addition, extracts from plant stem cuts, leaves and bark were spotted on a TLC plate, kept under best solvent system and observed under $254 \mathrm{~nm}$ UV light. Best extracts of callus lines and plant materials were chosen and compared with the extract of agarwood under $254 \mathrm{~nm}$ UV light.

$\mathrm{Rf}$ (retention factor) was calculated using the following formula (Harborne, 1998);

$$
\mathrm{Rf}=\frac{\text { Distance Travelled by Solute }}{\text { Distance Travelled by Solvent }}
$$

\section{RESULTS AND DISCUSSION}

\section{Selection of the best extraction and eluting solvents for silica gel thin layer chromatography}

Several factors determine the efficiency of a chromatographic separation. The adsorbent should show a maximum selectivity towards the substances to be separated so that the differences in rate of elution will be large. Silica gel is the most common adsorbent used for routine TLC of organic compounds. The eluting solvent should also show good selectivity in its ability to desorb the compounds that are being separated. The solubility of different compounds in the eluting solvent plays an important role in determining how fast they move up the TLC plate. However, a more important property of the solvent is its ability to be adsorbed on the adsorbent. Based on the extent of affinity of the solvent for the adsorbent, different compounds move at different rates, resulting in separation.

Among the three solvents (hexane, ethyl acetate and methanol) used in this study for extraction, ethyl acetate extracted a higher number of phytochemicals present in callus of
G. walla. (Plate 1b). Therefore, ethyl acetate was selected as the best solvent for TLC.
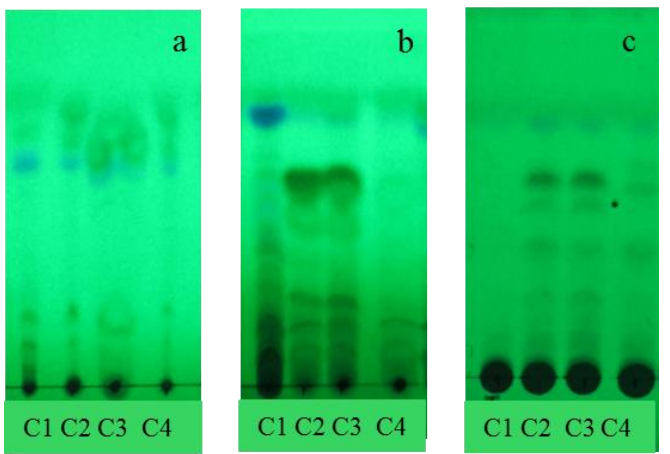

Plate 1: TLC finger print profiles of callus samples extracted with different organic solvents, hexane (a), ethyl acetate (b) and methanol (c).

Note: MS medium with $1 \mathrm{mg} / \mathrm{L} \mathrm{BAP}$ and $0.1 \mathrm{mg} / \mathrm{L} \mathrm{2,4-D}$ (C1), $0.5 \mathrm{mg} / \mathrm{L} \mathrm{2,4-D} \mathrm{(C2),} 1.0 \mathrm{mg} / \mathrm{L} \mathrm{2,4-D} \mathrm{(C3)} \mathrm{and} 2$ $\mathrm{mg} / \mathrm{L}$ 2,4-D (C4).

The ethyl acetate extracts of two callus lines C6 and C10 (chosen based on higher growth rates and fastest cell doubling) were run on different eluting solvent systems. The highest number of TLC spots was observed when the ethyl acetate extracts were eluted on $15 \%$ methanol: chloroform (Plate 2 e) compared to other eluting solvents (Plate $2 \mathrm{a}-\mathrm{d}$ ). Therefore, the eluting solvent system of $15 \%$ methanol: chloroform was selected as the suitable mobile phase based on the elution of TLC spots (Plate $2 \mathrm{e}$ ).
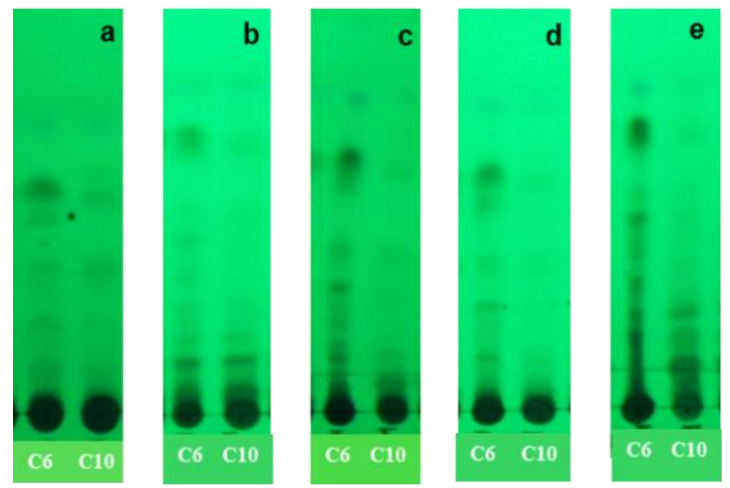

Plate 2: Thin layer chromatography fingerprints of ethyl acetate extracts of two callus lines (C6 and C10) under different solvent systems.

Note: C6:MS+ $1.0 \mathrm{mg} / \mathrm{L}$ BAP + $0.5 \mathrm{mg} /$ Lkinetin + 0.1 $\mathrm{mg} / \mathrm{L} 2,4-\mathrm{D}$; C10: MS containing $825 \mathrm{mg} / \mathrm{L}$ of $\mathrm{NH}_{4} \mathrm{NO}_{3}+$ $1.0 \mathrm{mg} / \mathrm{L} \mathrm{BAP}+0.1 \mathrm{mg} / \mathrm{L} \mathrm{2,4-D}$, a: $100 \% \mathrm{CHCl}_{3}$, b: $5 \%$ MeOH: $\mathrm{CHCl}_{3}$, c: $10 \% \mathrm{MeOH}: \mathrm{CHCl}_{3}$, d: 7:3:1 $\mathrm{CHCl}_{3}: \mathrm{MeOH}$ : $\mathrm{H}_{2} \mathrm{O}$, e: $15 \% \mathrm{MeOH}: \mathrm{CHCl}_{3}$ 
Detection of the effect of different plant growth regulators on the product synthesis by TLC

TLC fingerprint with a visible pattern of bands provides fundamental data and is typically used to determine the number of components in a mixture and to identity them. The compounds are identified by comparing the Rf of the compound with the Rf of a known compound, when both compounds are run on the same TLC plate (Reich and Schibli, 2006).

The effects of varying concentrations and combinations of plant growth regulators and reduced $\mathrm{NH}_{4} \mathrm{NO}_{3}$ contained MS medium on callus morphology and growth are shown in Plate 3.

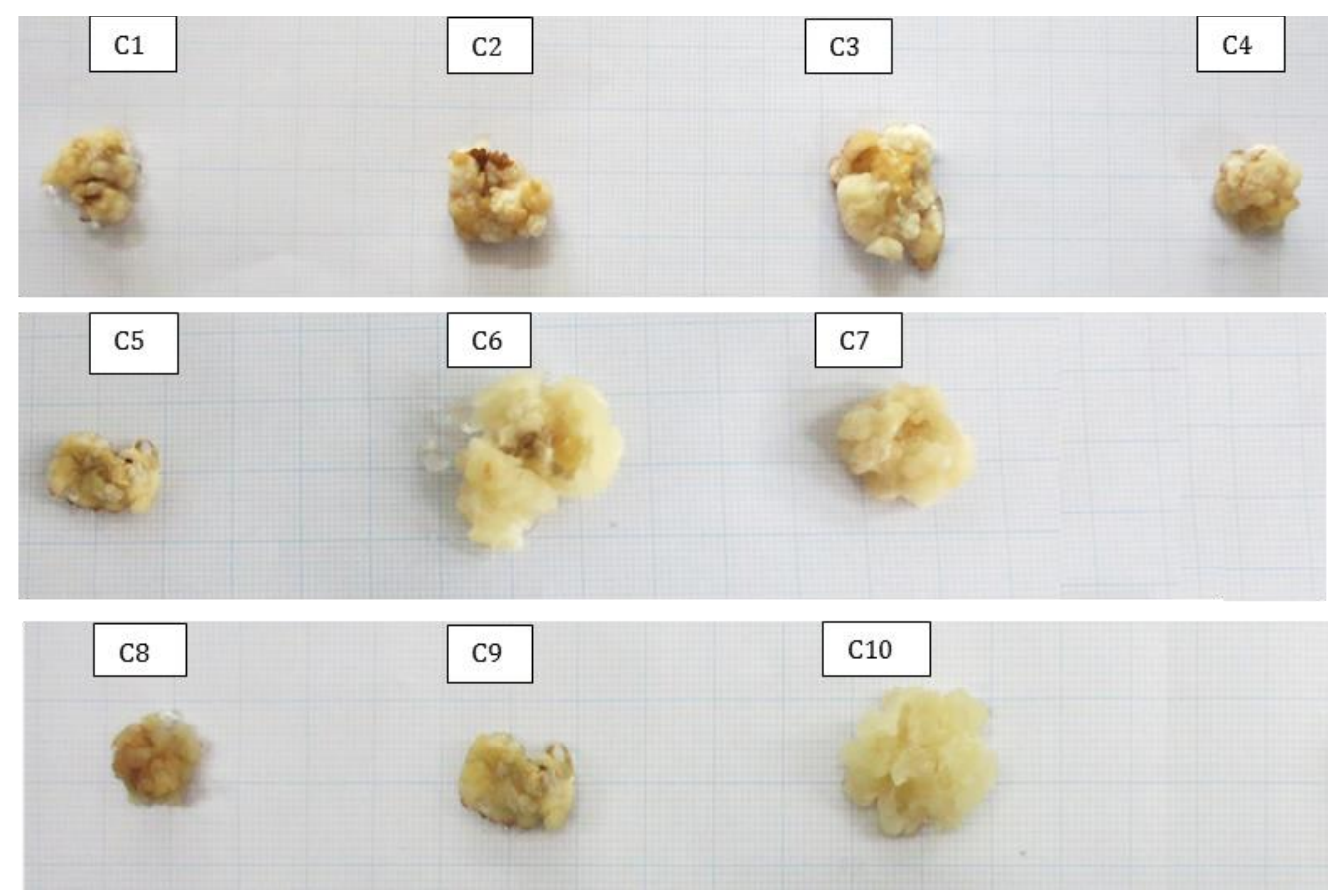

Plate 3. Callus developed on MS and modified MS media supplemented with different combinations and concentrations of plant growth regulators at 6 weeks after $4^{\text {th }}$ subculture (MS+1.0 mg/L BAP+ 0.1, 0.5, 1.0 and $2.0 \mathrm{mg} / \mathrm{L}$ of 2, 4-D (C1, C2, C3, C4 respectively), MS+ $1.0 \mathrm{mg} / \mathrm{L}$ BAP, $0.1 \mathrm{mg} / \mathrm{L} \mathrm{2,} \mathrm{4-D} \mathrm{and} \mathrm{0.1,} 0.5$ and $1.0 \mathrm{mg} / \mathrm{L}$ of kinetin (C5, C6 and C7 respectively) and four different levels of ammonium nitrate $(198 \mathrm{mg} / \mathrm{L}, 412.5 \mathrm{mg} / \mathrm{L}$ and $825 \mathrm{mg} / \mathrm{L}$ ) in MS medium with $1.0 \mathrm{mg} / \mathrm{L} \mathrm{BAP}$ and $0.1 \mathrm{mg} / \mathrm{L} \mathrm{2,} \mathrm{4-D} \mathrm{(C8,} \mathrm{C9} \mathrm{and} \mathrm{C10).}$

Results of the experiment done to study the influence of different plant growth regulators in culture media on product synthesis, using the $15 \%$ methanol: chloroform solvent system, showed that there was a strong influence of plant growth regulators on product synthesis (Plate 4). The number of spots appeared on the plate and the intensity of those spots indicates the number of chemicals present and concentration of the chemicals presents in the extracts. From these results it is clear that there was no increase in the number or thickness of the spots visible on the TLC plate with the increase in 2, 4-D concentration in the medium (C1, C2, C3 and C4 lines in Plate 4a). Calli grown in the presence of kinetin produced a higher number of thick spots (C5 C6 and C7 line in Plate 4a). Furthermore, the number and thickness of the spots increased with the increase of kinetin concentration from 0.1 (C5) to 0.5 (C6) $\mathrm{mg} / \mathrm{L}$ and decreased with further increase up to 1.0 $\mathrm{mg} / \mathrm{L}$ (C7) indicating that there should be fine balance between cytokinin and auxins concentrations to regulate the chemical synthesis within the cell. Interestingly, four spots were identified with similar retention factor in all callus lines at the Rf values of 0.10 , 
$0.19,0.27$ and 0.35 (Table I). Furthermore, when the media contained kinetin, thickness of these 3 spots (C5, C6, C7) were also increased compared to the media consisted with 2, 4-D (C1, C2, C3, C4).
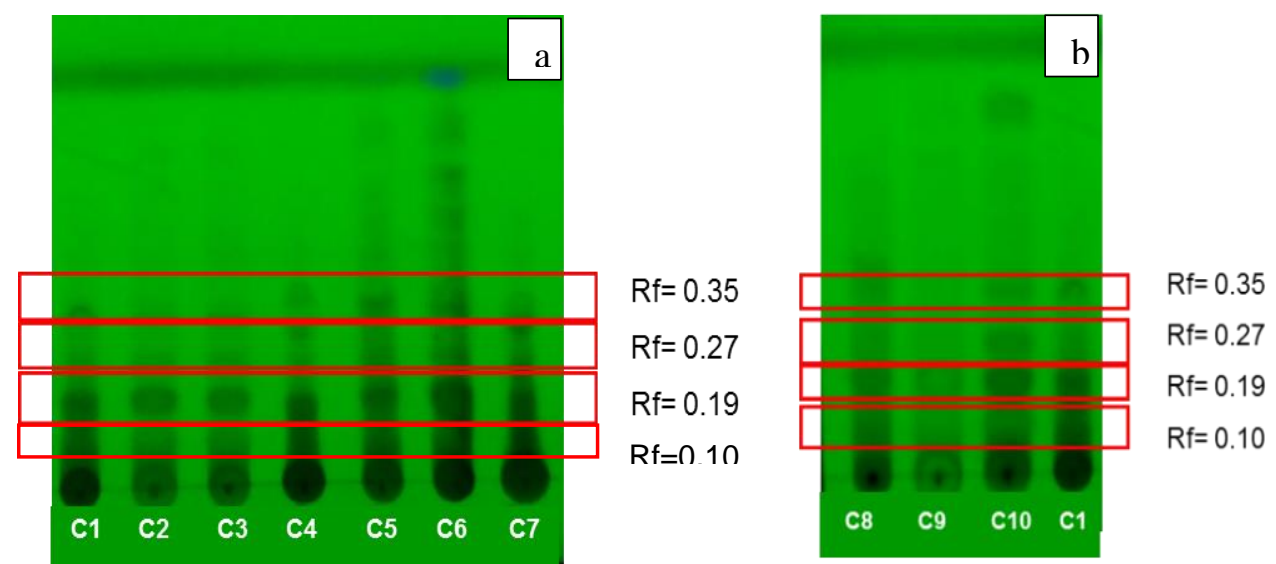

Plate 4: TLC fingerprint profile of ethyl acetate extracts of callus lines developed on MS (a) and modified MS medium (b) supplemented with different combinations and concentrations of plant growth regulators under 15\% methanol: chloroform.

Note: MS+ $1.0 \mathrm{mg} / \mathrm{L}$ BAP+ 0.1, 0.5, 1.0 and $2.0 \mathrm{mg} / \mathrm{L}$ of 2, 4-D (C1, C2, C3, C4 respectively), MS+ $1.0 \mathrm{mg} / \mathrm{L} \mathrm{BAP,} 0.1 \mathrm{mg} / \mathrm{L}$ 2, 4-D and $0.1,0.5$ and $1.0 \mathrm{mg} / \mathrm{L}$ of kinetin (C5, C6 and C7 respectively) and four different levels of ammonium nitrate (198 mg/L, $412.5 \mathrm{mg} / \mathrm{L}$ and $825 \mathrm{mg} / \mathrm{L}$ ) in MS medium with $1.0 \mathrm{mg} / \mathrm{L}$ BAP and $0.1 \mathrm{mg} / \mathrm{L} 2$, 4-D (C8, C9 and C10'

Ethyl acetate extracts of callus samples cultured on MS medium at decreased levels of $\mathrm{NH}_{4} \mathrm{NO}_{3}$ were also compared with MS medium with full $\mathrm{NH}_{4} \mathrm{NO}_{3}$ concentration that contained same levels of BAP and 2,4-D. TLC fingerprint showed that larger numbers of intense spots developed in MS medium contained half level of $\mathrm{NH}_{4} \mathrm{NO}_{3}(825 \mathrm{mg} / \mathrm{L})$ supplemented with 1.0 $\mathrm{mg} / \mathrm{L} \mathrm{BAP}$ and $0.1 \mathrm{mg} / \mathrm{L} 2,4-\mathrm{D}$ (C10). Four spots were observed at similar $\mathrm{Rf} 0.10,0.19$, 0.27 and 0.35 in all four callus lines (Plate $4 \mathrm{~b}$ ).

The results of the present study indicated that by reducing the $\mathrm{NH}_{4} \mathrm{NO}_{3}$ concentration to half, product synthesis of $G$. walla callus cultures can be enhanced. Ochoa-Villarreal et al. (2016) and Bhojwani and Dantu (2013) have reported that modification of the carbohydrate: nitrogen ratio is an effective technique to enhance the production of secondary metabolites. Ratnadewi (2016) mentioned that the nitrogen concentration of the culture medium influence the synthesis of alkaloids.

Research by Liu et al. (2013) revealed that in Anisodusa cutangulus hairy root culture, alkaloid yields were inhibited at low or high total nitrogen concentrations and the most favorable concentration of nitrogen gave the highest tropane alkaloid yield. Sujanya et al. (2008) reported that reduction in nitrogen source in cell suspension cultures of neem enhanced production of extracellular azadirachtin by 1.5 -fold.

When ethyl acetate extracts of all the callus lines were cultured on different media at varying combinations and concentrations of growth regulators and reduced level of nitrogen concentrations, spots were produced at similar $\mathrm{Rf}$ values $(0.10,0.19,0.27$ and 0.35$)$. This result revealed that these four compounds might be present in all the callus lines (Table 2).

Furthermore, TLC results clearly indicated that there should be a fine balance between the auxin and cytokinin concentrations for the synthesis of chemicals by cell cultures of $G$. walla. According to the results of TLC profiles, C6 (MS+ $1.0 \mathrm{mg} / \mathrm{L} \mathrm{BAP+} 0.5 \mathrm{mg} / \mathrm{L}$ kinetin+ 0.1 $\mathrm{mg} / \mathrm{L} 2,4-\mathrm{D}$ ) and $\mathrm{C} 10$ (half strength $\mathrm{NH}_{4} \mathrm{NO}_{3}$ containing MS medium $+1.0 \mathrm{mg} / \mathrm{L} \mathrm{BAP}+0.1$ $\mathrm{mg} / \mathrm{L} 2$, 4-D) were chosen as best callus lines. These were compared with the extracts of 
plant samples (i.e. bark and stem cuts and agarwood of $G$. walla) under identical chromatography conditions (Plate 5). Similar spots at Rf values of $0.60,0.66,0.78$ and 0.87 , indicated that four similar, less polar compounds were present in callus, plant and infected heart wood of G. walla.

Table 2: Retention values of callus cultured on MS and modified MS medium supplemented with different levels of plant growth regulators.

\begin{tabular}{|c|c|c|}
\hline Retention values & Treatment codes & Intensity of spots \\
\hline \multirow[t]{10}{*}{0.10} & $\mathrm{C} 1$ & +++ \\
\hline & $\mathrm{C} 2$ & ++ \\
\hline & C3 & ++ \\
\hline & $\mathrm{C} 4$ & +++ \\
\hline & $\mathrm{C} 5$ & +++ \\
\hline & C6 & +++ \\
\hline & C7 & +++ \\
\hline & C8 & +++ \\
\hline & C9 & + \\
\hline & C10 & +++ \\
\hline \multirow[t]{10}{*}{0.19} & $\mathrm{C} 1$ & +++ \\
\hline & $\mathrm{C} 2$ & +++ \\
\hline & C3 & +++ \\
\hline & $\mathrm{C} 4$ & +++ \\
\hline & $\mathrm{C} 5$ & +++ \\
\hline & C6 & +++ \\
\hline & $\mathrm{C} 7$ & +++ \\
\hline & $\mathrm{C} 8$ & +++ \\
\hline & C9 & ++ \\
\hline & C10 & +++ \\
\hline \multirow[t]{10}{*}{0.27} & $\mathrm{C} 1$ & + \\
\hline & $\mathrm{C} 2$ & + \\
\hline & C3 & + \\
\hline & C4 & + \\
\hline & $\mathrm{C} 5$ & +++ \\
\hline & C6 & +++ \\
\hline & $\mathrm{C} 7$ & ++ \\
\hline & $\mathrm{C} 8$ & ++ \\
\hline & C9 & + \\
\hline & $\mathrm{C} 10$ & +++ \\
\hline \multirow[t]{10}{*}{0.35} & $\mathrm{C} 1$ & + \\
\hline & $\mathrm{C} 2$ & + \\
\hline & C3 & + \\
\hline & $\mathrm{C} 4$ & + \\
\hline & C5 & +++ \\
\hline & C6 & +++ \\
\hline & $\mathrm{C} 7$ & ++ \\
\hline & $\mathrm{C} 8$ & ++ \\
\hline & C9 & + \\
\hline & C10 & +++ \\
\hline
\end{tabular}


Fingerprints of thin layer chromatography for comparing best callus lines, plant sample and agar wood of $G$. walla extracts

Based on the results of previous experiments, best extracts of callus lines (i.e. C6; cultured on MS medium supplemented with $1.0 \mathrm{mg} / \mathrm{L} \mathrm{BAP,}$ $0.5 \mathrm{mg} / \mathrm{L}$ kinetin and $0.1 \mathrm{mg} / \mathrm{L} 2,4-\mathrm{D}$, and C10; modified MS medium with reduced $\mathrm{NH}_{4} \mathrm{NO}_{3}$ concentration $(825 \mathrm{mg} / \mathrm{L})$ added with 1.0 $\mathrm{mg} / \mathrm{L} \mathrm{BAP}$ and $0.1 \mathrm{mg} / \mathrm{L} 2,4-\mathrm{D}$ ) and best plant extracts of stem cut (P1) and bark (P3) were compared with the extract of agarwood of $G$. walla (Ag) using TLC.

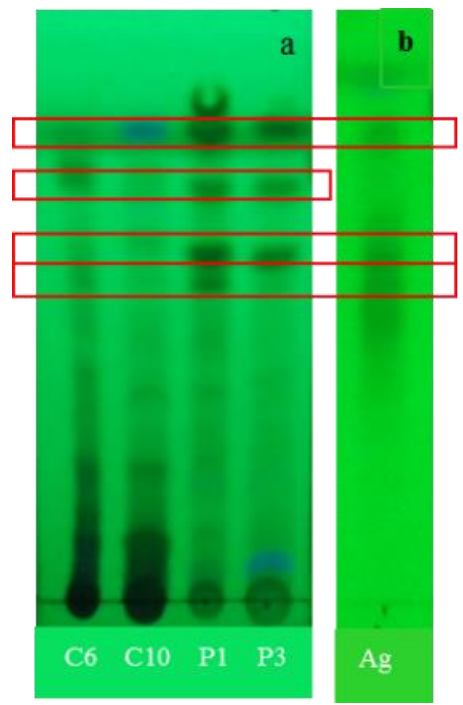

$\mathrm{Rf}=0.87$

$\mathrm{Rf}=0.78$

$\mathrm{Rf}=0.66$

$\mathrm{Rf}=0 . .60$

Plate 5: TLC fingerprint profiles developed for comparing ethyl acetate extracts of callus and plant samples with infected heart wood of $G$. walla under $15 \%$ Methanol: chloroform solvent system.

a: best callus lines (C6 and C10) and plant samples (P1 and P3); b: infected heart wood of G.walla (Ag).

Similar spots were identified among the ethyl acetate extracts of best callus lines, stem, bark and agarwood at the retention factors of 0.60 , $0.66,0.78$ and 0.87 (Plate 5) indicating that callus cultures are producing very similar compounds to chemicals produced by agarwood of the $G$. walla. However, based on intensity of spots, quantity of compounds present at $R f$ values of 0.66 and 0.78 was lower in callus samples compared to plant samples. Hence, to enhance the production of phytochemical constituents through plant cell culture, elicitation strategy could be used. Moreover, spots which were observed in callus lines at $\mathrm{Rf}=0.10,0.19,0.27$ and 0.35 , were not present in plant and agarwood of $G$. walla.

Therefore, it is essential to conduct further studies for identification of fragrance compounds from the cell cultures of G. walla.

\section{CONCLUSION}

Based on the results of present study, ethyl acetate was selected as the best extracting chemical from callus and plant samples of agarwood while 15\% methanol: chloroform was the best eluting solvent for silica gel TLC. TLC chromatographic finger prints revealed that there might be four similar compounds ( $R f$ values of $0.60,0.66,0.78$ and 0.87 ) which can be used as possible markers for G. walla, which were present in the ethyl acetate crude extracts of callus stem cuts, barks and agarwood. This preliminary study has proven that similar compounds as present in plant and agarwood of $G$. walla could be produced through plant cell culture techniques. Further investigations on two selected callus lines to identify the specific chemicals responsible for the peculiar fragrance of agarwood are essential to develop a protocol for the production of agarwood fragrance compounds through plant cell and tissue culture of $G$. walla.

\section{ACKNOWLEDGEMENT}

The authors would like to thank the National Research Council, Sri Lanka for providing financial support to this study (Grant No. NRC 17-017).

\section{REFERENCES}

Bhojwani, S.S. and Dantu, P.K. (2013). Production of industrial phytochemicals. In: Plant Tissue Culture- An Introductory Text. Ed. Bhojwani, S.S. and Dantu, P.K., Springer Com Publications.

Harborne, J.B. (1998). Phytochemical methods: A Guide to modern techniques of plants analysis. Chapman and Hall, London.

Itankar, P.R., Sawant, D.B., Tauqeer, M. and Charde, S.S. (2015). High performance thin layer chromatography fingerprinting, phytochemical and physico-chemical studies 
of anti-diabetic herbal extracts. Ayu, 36(2):188-95,doi:10.4103/0974-8520. 17554

Lima, E.C., Paiva, R., Nogeira, C., Soares, F.P., Emrich, E.B. and Silva, A.N. (2008). Callus induction in leaf segments of Croton urucurana Baill. Journal of Agrotechnology, 32: 17-22.

Liu, Q., Cui, L., Guo, Y., Ni, X., Zhang, Y. and Kai, G. (2013). Optimization of nutritive factors in culture media for growth and tropane alkaloid production from Anisodusa cutangulus hairy roots. Journal of Applied Pharmaceutical Science, 3(1):01-04.

Murashige, T. and Skoog, F.A. (1962). A revised medium for rapid growth and bioassays with tobacco tissue cultures. Physiologia Plantarum, 15: 473-497.

Nurazah, Z., Radzali, M., Syahida, A. and Maziah, M. (2009). Effects of plant growth regulators on callus induction from Cananga odorata flower petal ex-plants. African Journal of Biotechnology, 8(12): 2740-2743.

Ochoa-Villarreal, M., Howat, S., Hong, S., Jang, M. O., Jin, Y.W., Lee, E.K. and Loake, G.J. (2016). Plant cell culture strategies for the production of natural products. BMB reports, 49(3), 149-158.

Okudera, Y. and Ito, M. (2009). Production of agarwood fragrant constituents in Aquilaria calli and cell suspension nutrients. Plant Biotechnology, 26: $307-$ 315.

Reich, E. And Schibli, A. (2006). HighPerformance Thin-Layer Chromatography for the Analysis of Medicinal Plants. Thieme, New York, USA.

Selvaskanthan, S., Pushpakumara, D.K.N.G. and Eeswara, J.P. (2018). Development of a Protocol for In vitro Establishment of Gyrinops walla. Tropical Agricultural Research, 29 (3): 330 - 336.

Shu, Y.Q., Meng, L.H., Li, D.I., Chuan, H.Z., Lan, J.H. and Hui, Z.Z. (2005). Production of 2-(2phenylethyl) chromones in cell suspension cultures of Aquilaria sinensis. Plant Cell, Tissue and Organ Culture, 83: 217-221.

Subasinghe, S.M.C.U.P. and Hettiarachchi, D.S. (2013). Agarwood resin production and resin quality of Gyrinops walla Gaertn. International Journal of Agricultural Sciences, 3(1).

Sujanya, S., Devi, B.P. and Sai, I. (2008). In vitro production of azadirachtin from cell suspension cultures of Azadirachta indica. Journal of Bioscience, 33(1):113-120.

Vanisree, M., Lee, C.Y., Lo, S.F., Nalawade, S.M., Lin, C.H. and Tsay, H.S. (2004). Studies on the production of some important secondary metabolites from medicinal plants by plant tissue cultures. Botanical Bulletin of Academia Sinica, 45: 357-362. 